\title{
PENGKAJIAN YANG TEPAT DALAM PROSES KEPERAWATAN SEBAGAI AWAL PEMBERIAN ASUHAN KEPERAWATAN YANG BERKUALITAS
}

\author{
Elisa Claudia Simanjuntak / 181101114 \\ elclaudia02@gmail.com
}

\begin{abstract}
ABSTRAK
Latar Belakang : Perawat memilki fokus dalam praktiknya sebagai pemberi asuhan keperawatan primer. Dalam memberikan asuhan keperawatan, perawat harus selalu berpikir kritis tentang respon klien terhadap masalah kesehatannya, agar dapat memberikan perawatan yang efektif kepada klien. Untuk memudahkan pendekatan dengan klien, perawat harus melakukan suatu sistem yang disebut dengan proses keperawatan.

Tujuan : Tujuan penulisan kajian ini adalah untuk mengetahui gambaran asuhan keperawatan yang berkualitas melalui proses keperawatan pada tahap pengkajian.

Metode : Metode yang digunakan dalam kajian ini adalah literature review, yaitu dengan cara menganalisis, mengeksplorasi serta mengkaji bebas jurnal dan buku teks yang membahas tentang pengkajian dan gambaran asuhan keperawatan yang berkualitas dalam proses keperawatan.

Hasil : Hasil kajian menunjukkan bahwa pengkajian keperawatan yang dilakukan dengan tepat dapat menjadi awal pemberian asuhan keperawatan yang berkualitas. Pada tahap ini, perawat melakukan pengumpulan informasi mengenai kondisi klien. Pengkajian yang dilakukan oleh perawat secara akurat menjadi awal dalam menerapkan asuhan keperawatan yang benar dan berkualitas.

Pembahasan : Tahap awal dalam proses keperawatan adalah pengkajian. Pada tahap ini, perawat membuat pengamatan klinis tentang kondisi klien, melaporkan situasi klien yang berhubungan dengan masalah medis, dan mengikuti aktivitas medis klien yang didelegasikan oleh dokter (Potter \& Perry, 2005). Perawat harus mengumpulkan data klien dengan menerapkan pengetahuan dan pengalamannya.
\end{abstract}

Kata Kunci : Pengkajian Keperawatan, Proses Keperawatan, Asuhan Keperawatan. 


\section{Latar Belakang}

Perawat dalam melakukan tugasnya memberikan asuhan kepada klien harus cepat, tepat, dan akurat. Dalam melaksanakan asuhan keperawatan, perawat dapat menerapkan suatu sistem yang disebut dengan proses keperawatan. Melalui proses keperawatan, diharapkan perawat mampu bertindak secara sistematis dan terorganisir. Tindakan atau asuhan keperawatan yang dilakukan perawat secara sitematis dan terorganisir memudahkan perawat untuk melakukan intervensi keperawatan yang tepat dan berkualitas.

Proses keperawatan adalah suatu sistem atau metode yang sistematis dan terorganisir dalam pemberian asuhan keperawatan yang difokuskan pada reaksi dan respon unik individu pada suatu kelompok atau perorangan terhadap gangguan kesehatan yang dialami, baik aktual maupun potensial (Deswani, 2009). Pada proses keperawata, pengkajian merupakan tahap awal dimana perawat menerapkan ilmu pengetahuan serta pengalamannya. Perawat harus mampu bertindak dengan mengedepankan berpikir kritis.

Pada tahap pengkajian, perawat membuat pengamatan terhadap kondisi klien. Dalam perannya memberi asuhan keperawatan yang berkualitas, perawat harus mengkaji kondisi klien dengan benar dan melakukan intervensi keperawatan untuk membantu klien mempertahankan maupun memperbaiki kesehatannya. Penting bagi perawat untuk melakukan pengkajian terhadap kondisi klien dengan tepat.

Sebagai tahap awal, melalui pengkajian diharapkan hasilnya dapat menjadi patokan dalam menentukan intervensi keperawatan yang tepat. Namun, bukan berarti pengkajian hanya dilakukan sekali saja. Apabila pengkajian telah dilakukan dengan tepat dan akurat, harapannya tindakan atau asuhan keperawatan yang diberikan berkualitas, sehingga tujuan perawat untuk memperbaiki kesehatan klien tercapai.

\section{Tujuan}

Pengkajian ini dilakukan untuk mengetahui bagaimana pengkajian dalam proses keperawatan menjadi tahap awal pemberian asuhan keperawatan yang berkualitas.

\section{Metode}

Metode yang digunakan dalam kajian ini adalah literature review, yaitu 
dengan cara menganalisis, mengeksplorasi serta mengkaji bebas jurnal dan buku teks yang membahas tentang pengkajian keperawatan, asuhan keperawatan yang berkualitas dan proses keperawatan. Referensi berupa jurnal dan buku teks yang digunakan adalah sebanyak 14. Jurnal yang digunakan sebagai referensi dalam tulisan ini diterbitkan dalam kurun waktu 10 tahun terakhir.

\section{Hasil}

Dari hasil pengkajian ditemukan bahwa pengkajian keperawatan yang dilakukan dengan tepat dan hasil yang akurat akan membantu perawat menentukan intervensi keperawatan yang tepat. Tahap pengkajian dilakukan dengan mengumpulkan data, menganalisis data, mengelompokkan data, dan dokumentasi data. Klien dan keluarganya menjadi sumber data dalam tahap ini.

Hasil pengkajian yang akurat menjadi awal dalam proses keperawatan dalam memberikan asuhan keperawatan yang berkualitas oleh perawat. Pada saat melakukan pengkajian, hubungan saling percaya antara perawat dengan klien juga dapat terjalin. Hubungan saling percaya tersebut dapat membuat klien lebih terbuka mengenai kondisinya, sehingga memudahkan perawat dalam melakukan tugasnya.

\section{Pembahasan}

Dalam menjalankan tugasnya, perawat harus mampu memecahkan masalah secara akurat, cepat, dan menyeluruh. Perawat dapat bekerja mengikuti suatu sistem atau metode yang disebut dengan proses keperawatan. Proses keperawatan terdiri dari lima tahap. Proses keperawatan bertujuan untuk membantu perawat menentukan intervensi keperawatan yang tepat.

Tahap pertama dalam proses keperawatan adalah pengkajian. Pengkajian keperawatan adalah proses sistematis dari pengumpulan, verifikasi, dan komunikasi data tentang klien (Potter \& Perry, 2005). Adapun informasi didapatkan dari klien maupun keluarganya. Dalam melakukan pengkajian, perawat dapat menerapkan pengetahuan dan pengalamannya untuk memperoleh informasi dari klien.

Tahap pengkajian meliputi pengumpulan data, analisis data, pengelompokan data, dan dokumentasi data. Pengumpulan data dilakukan mulai dari saat klien datang dan selama 
proses keperawatan berlangsung. Data yang dikumpulkan dibedakan menjadi dua, yaitu data objektif dan data subjektif. Data objektif adalah data yang dapat dilihat langsung dan diobservasi oleh perawat. Sedangkan, data subjektif adalah data yang berasal dari pernyataan klien mengenai kondisinya.

Pengumpulan data dapat dilakukan dengan melakukan wawancara, observasi, maupun pemeriksaan fisik.

1. Wawancara

Wawancara antara perawat dengan klien adalah kegiatan tanya jawab yang berhubungan dengan kondisi klien. Wawancara dapat dilakukan secara langsung maupun tidak langsung. Wawancara langsung adalah wawancara yang dilakukan perawat langsung dengan klien. Sedangkan, wawancara tidak langsung adalah wawancara yang dilakukan perawat dengan keluarga klien maupun sumber lain untuk memperoleh informasi mengenai kondisi klien.

Wawancara yang dilakukan oleh perawat bukan saja untuk memperoleh data, namun juga meningkatkan hubungan yang baik antara klien dan perawat. Pada saat wawancara pun, perawat dapat membangun rasa percaya klien terhadap perawat. Hal ini dilakukan agar klien dapat lebih terbuka mengenai kondisinya.

\section{Observasi}

Observasi (pengamatan) yang dilakukan perawat merupakan kegiatan untuk mengumpulkan data atau informasi mengenai kondisi klien, baik dengan cara melihat, mendengar, maupun meraba. Data observasi yang tepat dan akurat tergantung kepada pengetahuan dan pengalaman perawat. Sebaiknya, sebelum melakukan observasi terhadap kondisi klien, perawat harus memperdalam ilmu pengetahuannya agar data yang dikumpulkan selama observasi akurat.

\section{Pemeriksaan Fisik}

Pemeriksaan fisik dilakukan untuk mengumpulkan data mengenai kondisi fisik klien. Pemeriksaan fisik ini dapat dilakukan dengan teknik inspeksi, palpasi, perkusi, dan auskultasi. Data yang dikumpulkan dari pemeriksaan fisik dapat digunakan untuk mengevaluasi kondisi klien. Data yang terkumpul selama pemeriksaan fisik ini dapat berupa data subjektif maupun objektif.

Setelah data yang terkumpul dirasa cukup, perawat dapat menentukan mana data yang penting dan valid. Setiap data 
tersebut kemudian dianalisis sesuai dengan masalah di dapat. Kemudian, data yang sudah dianalisis dan valid tersebut di kelompokkan. Selanjutnya, dilakukan dokumentasi data. Dokumentasi data merupakan bagian terakhir dari pengkajian. Pada saat dokumentasi, semua data yang didapatkan dari berbagai sumber, ditulis secara lengkap dan relevan.

\section{Penutup}

Pengkajian dalam proses keperawatan merupakan tahap awal yang penting untuk dilakukan secara tepat. Nantinya hasil dari pengkajian ini akan membantu perawat untuk melakukan proses keperawatan selanjutnya dengan tepat. Pengkajian merupakan tahap dimana dilakukan pengumpulan data, analisis data, pengelompokan data, dan dokumentasi data. Jika awal dari proses keperawatan ini sudah tepat dan akurat, penentuan intervensi keperawatan pun diharapkan tepat sehingga asuhan keperawatan yang nantinya akan diberikan kepada pasien dapat dikatakan berkualitas.

Untuk dapat melakukan pengkajian dengan benar dan hasilnya akurat, perawat diharapkan untuk memperbanyak pengetahuan dan pengalamannya.

\section{Referensi}

Achmadi, L, Linnie Pondang \& Abram Babakal. (2015). Gambaran Tingkat Pengetahuan Perawat dalam Penerapan Standar Asuhan Keperawatan di Ruangan Rawat Inap Interna RSUD Datoe Bhinangkang. eJurnal Keperawatan. 3(3).

Allen, Carol V, Effendy C, \& Setiawan. (1998). Memahami

Proses

Keperawatan dengan Pendekatan Latihan. Jakarta: EGC.

Deswani. (2009). Proses Keperawatan dan Berpikir Kritis. Jakarta: Salemba Medika.

Haryanto. (2008). Konsep Dasar Keperawatan dengan Pemetaan Konsep (Concept Mapping). Jakarta: Salemba Medika.

Herdman, T. H. \& Shigemi Kamitsuru. (2018). NANDA International Nursing Diagnoses: Definitions and Classification (2018-2020). Jakarta: EGC.

Lestari, Tri Rini Puji. (2014). Pendidikan Keperawatan: 
Upaya Menghasilkan Tenaga Perawat Berkualitas. Aspirasi. 5(1).

Lismidar, H., dkk. (1990). Proses Keperawatan. Jakarta: UI Press.

Maryam, Siti, dkk. (2006). Buku Ajar Berpikir Kritis dalam Proses Keperawatan. Jakarta: EGC.

Nogo, Antonia. (2014). Kinerja Perawat dalam Penerapan Standar Asuhan Keperawan di Rumah Sakit Umum Daerah Naibonat Kabupaten Kupang. Jurnal Penelitian. 18(1): 62-66.

Potter \& Perry. (2005). Buku Ajar Fundamental Keperawatan: Konsep, Proses, dan Praktik Edisi 4. Jakarta: EGC.

Rutami \& Setiawan. (2012). Pelaksanaan Proses Pengkajian Keperawatan di Ruang Rawat Inap RSUP H. Adam Malik Medan. Jurnal Keperawatan Holistik. 1(2): 52-57.

Susanto, Rachmat. (2010). Penerapan Standar Proses Keperawatan di Puskesmas Rawat Inap Cilacap. Jurnal Keperawatan Soedirman. 5(2): 80-83.
Tarwoto \& Wartonah. (2012).

Kebutuhan Dasar Manusia dan Proses Keperawatan. Jakarta: Salemba Medika.

Vaughans, Bennita W. (2013). Keperawatan Dasar. Yogyakarta: Rapha Publishing. 